\title{
Mercury levels and tolerable weekly intakes (TWI) of tuna and tuna- like species from the Southern Indian Ocean (Indonesia): Public health perspective
}

\author{
TRI HANDAYANI ${ }^{1, \bullet}$, MOHAMAD SYAMSUL MAARIF ${ }^{2}$, ETTY RIANI ${ }^{3}$, NAZORI DJAZULI ${ }^{4}$ \\ ${ }^{1}$ Natural Resources and Environmental Management, Graduate School, Institut Pertanian Bogor. Gedung Sekolah Pascasarjana Lt. II Kampus IPB \\ Baranangsiang, Bogor 16144, West Java, Indonesia. Tel.: +62-251-8332779, `email: yen.han27@ gmail.com \\ ${ }^{2}$ Business Program, Graduate School, Institut Pertanian Bogor. Jl. Raya Dramaga, Bogor 16980, West Java, Indonesia \\ ${ }^{3}$ Department of Aquatic Resources Management, Faculty of Fisheries and Marine Science, Institut Pertanian Bogor. Jl. Raya Dramaga, Bogor 16980, \\ West Java, Indonesia \\ ${ }^{4}$ PT. Dharma Samudera Fishing Industries, Tbk. Jakarta, Indonesia
}

Manuscript received: 4 November 2018. Revision accepted: 27 January 2019.

\begin{abstract}
Handayani T, Maarif MS, Riani E, Djazuli N. 2019. Mercury levels and tolerable weekly intakes (TWI) of tuna and tuna-like species from the Southern Indian Ocean (Indonesia): Public health perspective. Biodiversitas 20: 504-509. Tuna and tuna-like species are essential sources of protein for much of the world and provide employment in areas where fishing and processing are concentrated, as well as their value are confirmed as extremely valuable. However, their benefits may be overshadowed by the presence of mercury. The main objectives of the study were to analyze mercury content in tuna and tuna-like caught from Southern Indian Ocean related to its correlation with the weight of fish. The method used was linear regression and tolerable weekly intake (TWI) calculation. Mercury levels in yellowfin tuna (Thunnus albacares) and bigeye tuna (Thunnus obesus) indicated significant variations with the level that ranged from 0.049 to $0.654 \mathrm{mg} / \mathrm{kg}$ across individual fish weight, while for tuna-like ranged from 0.014 to $1.908 \mathrm{mg} / \mathrm{kg}$. All mercury levels in tuna not exceeded $1.0 \mathrm{mg} / \mathrm{kg}$, while for tuna-like $7.3 \%$ (30 kg up), 27.3\% (51 kg up) and $34 \%$ (51 kg up) for oilfish (Lepidocybium flavobrunneum), marlin (Makaira indica) and swordfish (Xiphias gladius) were exceeded of $1.0 \mathrm{mg} / \mathrm{kg}$ respectively. TWI calculation indicates that people who are not in high-risk categories (most adult and adolescents) may consume about $1,000 \mathrm{~g}$ of tuna a week and less than for tuna-like.
\end{abstract}

Keywords: Linear regression; mercury; tolerable weekly intake; tuna and tuna-like species

\section{INTRODUCTION}

Fish provide a healthful of dietary protein and are relatively low in cholesterol and high in omega-3 (n-3) fatty acid (USDA 2010). Fish consumption is known to have a beneficial effect on human health due to its nutrients, e.g., log chain n-3 polyunsaturated fatty acids that have beneficial effects on the neurodevelopment of children (Daniels et al. 2004; Mahaffey 2011). Tuna and tuna-like are considered comprised of many species, such as some species of tuna, swordfish, marlin including oilfish that are considered to be highly valuable. They support a large number of industries in many nations and generate more than the US $\$ 40$ billion a year for the global economy from the total production of almost 5 million metric tons (Galand et al. 2016). In 2012, the volume of landed tuna worldwide rose to 4.6 million metric tons, consist of $71 \%$ from the Pacific Ocean, $18 \%$ and $10 \%$ are from Indian and Atlantic Ocean respectively (PARM 2016). Tuna and tuna-like play an important role in Indonesia economy, generate foreign exchange and provide protein intake for the coastal community. Export of tuna and tuna-like from Indonesia in 2014 was 206,555 ton in volume with almost 700.000 US\$ (Galand et al. 2016).

Tuna fisheries are an important source of protein for most of the world. On the other hand, many studies have shown that mercury is bio amplified in the food chain, with high-tropic-level predatory species having higher mercury than herbivorous species (Nicklisch et al. 2017; Lacerda et al. 2017). Moreover, many studies advise that pregnant or soon to be a pregnant woman, infants and small children should limit eating tuna and tuna-like (EFSA 2015).

European Union Rapid Alert System for Food and Feed (EU RASFF) had reported tuna and tuna-like rejection due to mercury content yearly of which from 2014-2017 there are $99,85,98$ and 133 cases of rejection respectively (EU Commission 2017). Tuna and tuna-like will be rejected if the total mercury content higher than $1.0 \mathrm{mg} / \mathrm{kg}$. In 2001 , the US FDA issued consumption advisory, based on mercury, that pregnant woman and women of childbearing age who may become pregnant should avoid eating four species of saltwater fish: shark, swordfish, king mackerel and tilefish (FDA 2001). However, study also shown that there is evidence of variation of mercury levels among oceans and countries, probably related to the source of the fishery, species and fish weight (Storelli et al. 2006; Lavoie et al. 2018).

A joint Expert Committee on Food Additives constitute has recommended provisional tolerable weekly intakes (PTWI) of mercury concentrate of $5,0 \mu \mathrm{g} / \mathrm{kg}$ of body weight (FAO/WHO 2014), of which an adult who weighs to $60 \mathrm{~kg}$, maximum consumption of mercury about $300 \mu \mathrm{g}$ 
in a week. Furthermore, study carried out by Okyere et al. (2015), found that highest mercury concentration obtained from tuna of $0.2 \mu \mathrm{g} / \mathrm{g}$ and an adult must consume about $1,500 \mathrm{~g}$ of tuna per week in order to accumulate $300 \mu \mathrm{g}$ of mercury in a week which is the limit set by the Joint Expert Committee on Food Additives (FAO/WHO 2014). Although there are several published reports of mercury in fish, most studies have not distinguished between species tuna and tuna-like, as well as between weights within the same species from a trading or commercial perspective. The amount of mercury in fish is related to the age of fish and the position of the fish species within the food chain, predatory fish and older fish having a higher concentration than others (Mahaffey 2011; Sackett 2013). Thus, assessing the levels of mercury in tuna and tuna-like with different weight related to commercial and business as well as its PTWI of consumption is important from trading or commercial as well as public health perspective. The objectives of the study were to analyze mercury content in tuna and tuna-like related to the maximum level of rejection and its correlation with the weight of fish, as well as the calculation of provisional tolerable weekly intake (PTWI).

\section{MATERIALS AND METHODS}

\section{Source of mercury levels data}

The data were gathered from seven processing plants of tuna and tuna-like located in Jakarta Fishing Port-Jakarta, and Benoa-Bali, Indonesia where the tuna and tuna-like landed were caught from the Southern Indian Ocean. Those fish factories were processed tuna and tuna-like for export purposes mostly to US and EU countries in the form of loin, steak as well as a whole fish. Since those processing plant exported to EU and USA, the Indonesian competent authority required them to do monitoring of harmful substances, e.g. total mercury regularly, as requirements for hazard analysis critical control point (HACCP) implementation, EU approved establishments and $\mathrm{HC}$ issued. The sample taken shall be at random based on species, and weight of fish and mercury was analyzed in the ISO 17025 certified laboratory, equipped with atomic absorption spectrophotometer (AAS) analyzer.

\section{Data analysis}

Mercury concentration monitoring data from seven processing plants were gathered from 2012 to 2017, of which 758 total data were collected consists of 167 data, 126, 150, 150 and 165 for yellowfin tuna (Thunnus albacares), bigeye tuna (Thunnus obesus), oilfish (Lepidocybium flavobrunneum), swordfish (Xiphias gladius) and marlin (Makaira indica) respectively. The weight of fish divided into two groups based on market and trading specification, for tuna (yellowfin and bigeye) and tuna-like (swordfish and marlin) were $1-10 \mathrm{~kg}, 11-30 \mathrm{~kg}$, $31-50 \mathrm{~kg}, 51-100 \mathrm{~kg}$ and $100 \mathrm{~kg}$ up, while for oilfish were $1-5 \mathrm{~kg}, 6-10 \mathrm{~kg}, 11-15 \mathrm{~kg}, 16-30 \mathrm{~kg}$ and $30 \mathrm{~kg}$ up. The data were tabulated based on the classification of weight for each species and average (mean) of mercury level per processing factory to measure the correlation between mercury level and weight of fish; linear regression analysis was applied (Walpole 1982). PTWI values of mercury by an adult of $5 \mu \mathrm{g} / \mathrm{kg}$ body weight or equivalent to $300 \mu \mathrm{g}$ of $60 \mathrm{~kg}$ body weight (recommend by FAO/WHO 2004) were calculated using the average value of mercury by each fish species. PTWI calculated using the formula : maximum accumulated mercury per week $(300 \mu \mathrm{g})$ divided by a mean concentration of mercury of fish species.

\section{RESULTS AND DISCUSSION}

Total mercury content in tuna and tuna-like gathered from seven processing establishments located in Jakarta Fishing Port-Jakarta and Benoa-Bali consists of 167 data of yellowfin tuna and 126 of bigeye, while mercury content for tuna-like were 150,150 and 165 data for oilfish, swordfish, and marlin respectively. The data were collected from monitoring mercury required by Indonesian Competent Authority carried out by processing plants from the year 2012-2017. The total mercury content gathered were classified analyzed based on the weight of fish used in trading and commercial practices. Based on data of total mercury collected could be divided into two categories which are total mercury in tuna (yellowfin and bigeye) and tuna-like (oilfish, swordfish, marlin, and mahi-mahi).

\section{Total mercury in tuna}

The mean concentration of mercury in a different weight of yellowfin are shown in Table 1. The mean mercury levels ranged from the lowest of $0.085 \mathrm{mg} / \mathrm{kg}$ to the highest of $0.654 \mathrm{mg} / \mathrm{kg}$. There was a weak relationship between mercury content and weight of yellowfin tuna. The higher weight are not followed by the higher $\mathrm{Hg}$ concentration, of which the $\mathrm{Hg}$ contents fluctuated. Indeed, the fish with the highest concentration of $0.654 \mathrm{ppm}$ had found from B weight (11-30 kg) of yellowfin, while for the highest weight $\mathrm{E}$ of yellowfin (100 up) the highest concentration was $0.408 \mathrm{mg} / \mathrm{kg}$. The grand mean of mercury level of yellowfin weight was $0.175 \mathrm{mg} / \mathrm{kg} ; 0.301$ $\mathrm{mg} / \mathrm{kg} ; 0.247 \mathrm{mg} / \mathrm{kg} ; 0.331 \mathrm{mg} / \mathrm{kg}$ and $0.298 \mathrm{mg} / \mathrm{kg}$ for $\mathrm{A}$, $\mathrm{B}, \mathrm{C}, \mathrm{D}$ and $\mathrm{E}$ weight respectively. The rejection level of $1.0 \mathrm{mg} / \mathrm{kg}$ for tuna set by EU-FVO was no data exceeded the rejection level from 167 data gathered for yellowfin tuna.

The mean total mercury levels of bigeye in different weight are shown in Table 2 . Total mercury level means ranged from the lowest of $0.049 \mathrm{mg} / \mathrm{kg}$ to the highest of $0.514 \mathrm{mg} / \mathrm{kg}$. A trend of total mercury levels toward weight of bigeye tends to fluctuate and not increased toward the increase of the bigeye weight. The grand mean of mercury levels toward weight of bigeye were $0.096 ; 0.219 ; 0.279$; 0.155 and $0.327 \mathrm{mg} / \mathrm{kg}$ for $\mathrm{A}, \mathrm{B}, \mathrm{C}, \mathrm{D}$ and $\mathrm{E}$ weight respectively. The rejection level of $1.0 \mathrm{mg} / \mathrm{kg}$ for tuna set by EU-FVO was not exceeded by 126 data gathered for bigeye. 
Table 1. The average of total mercury in yellowfin tuna (Thunnus albacares)

\begin{tabular}{|c|c|c|c|c|c|c|c|c|c|c|c|}
\hline \multirow{2}{*}{ Weight (kg) } & \multicolumn{7}{|c|}{ The average of total mercury $\mathrm{mg} / \mathrm{kg} /$ processing plant } & \multirow{2}{*}{ Grand mean } & \multirow[b]{2}{*}{ Median } & \multirow[b]{2}{*}{$\mathbf{N}$} & \multirow[b]{2}{*}{ Std dev } \\
\hline & 1 & 2 & 3 & 4 & 5 & 6 & 7 & & & & \\
\hline$A(1-10)$ & 0.170 & 0.108 & 0.248 & 0.154 & 0.204 & 0.212 & 0.126 & 0.175 & 0.170 & 31 & 0.050 \\
\hline B $(11-30)$ & 0.274 & 0.173 & 0.127 & 0.471 & 0.085 & 0.654 & 0.324 & 0.301 & 0.274 & 37 & 0.2033 \\
\hline $\mathrm{C}(31-50)$ & 0.259 & 0.186 & 0.198 & 0.263 & 0.229 & 0.246 & 0.349 & 0.247 & 0.246 & 34 & 0.054 \\
\hline D (51-100) & 0.163 & 0.514 & 0.185 & 0.376 & 0.152 & 0.615 & 0.312 & 0.331 & 0.312 & 35 & 0.182 \\
\hline E (100 UP) & 0.303 & 0.261 & 0.280 & 0.279 & 0.408 & 0.173 & 0.381 & 0.298 & 0.280 & 28 & 0.078 \\
\hline
\end{tabular}

Table 2. The average of total mercury in bigeye tuna (Thunnus obesus)

\begin{tabular}{|c|c|c|c|c|c|c|c|c|c|c|c|}
\hline \multirow{2}{*}{ Weight (kg) } & \multicolumn{7}{|c|}{ The average of total mercury $\mathrm{mg} / \mathrm{kg} /$ processing plant } & \multirow[b]{2}{*}{ Grand mean } & \multirow[b]{2}{*}{ Median } & \multirow[b]{2}{*}{$\mathbf{N}$} & \multirow[b]{2}{*}{ Std dev } \\
\hline & 1 & 2 & 3 & 4 & 5 & 6 & 7 & & & & \\
\hline $\mathrm{A}(1-10)$ & 0.092 & 0.135 & 0.060 & NA & 0.128 & 0.070 & 0.092 & 0.096 & 0.092 & 23 & 0.030 \\
\hline B $(11-30)$ & 0.263 & 0.237 & 0.172 & 0.228 & 0.191 & 0.186 & 0.259 & 0.219 & 0.228 & 31 & 0.037 \\
\hline $\mathrm{C}(31-50)$ & 0.313 & 0.171 & 0.280 & 0.099 & 0.368 & 0.239 & 0.481 & 0.279 & 0.280 & 32 & 0.126 \\
\hline $\mathrm{D}(51-100)$ & NA & 0.049 & 0.149 & 0.101 & NA & 0.271 & 0.206 & 0.155 & 0.149 & 19 & 0.087 \\
\hline E (100 UP) & 0.514 & 0.139 & NA & 0.329 & 0.268 & NA & 0.386 & 0.327 & 0.329 & 21 & 0.139 \\
\hline
\end{tabular}

\section{Total mercury in tuna-like}

The mean concentration of total mercury of oilfish in the different weight reis shown in Table 3 . Total mercury level means ranged from the lowest of $0.014 \mathrm{mg} / \mathrm{kg}$ to the highest of $1,174 \mathrm{mg} / \mathrm{kg}$. Contrarily to bigeye tuna, strong effects were observed when examining the impact of weight on mean mercury levels, where total mercury increased linearly toward the increase of the fish weight. The grand mean of mercury level of oilfish toward oilfish weight were $0.045 ; 0.121 ; 0.329 ; 0.513$ and $1.026 \mathrm{mg} / \mathrm{kg}$ for $\mathrm{A}, \mathrm{B}, \mathrm{C}, \mathrm{D}$ and $\mathrm{E}$ weight respectively. The rejection level of $1.0 \mathrm{mg} / \mathrm{kg}$ for oilfish set by EU-FVO was exceeded by 11 out of 150 data gathered for oilfish (7.3\%).

The mean levels of total mercury of swordfish in the different weight of fish are shown in Table 4. Total mercury level means ranged from the lowest of 0.056 $\mathrm{mg} / \mathrm{kg}$ to highest of $1.657 \mathrm{mg} / \mathrm{kg}$. A trend of total mercury levels toward the weight of swordfish was increased significantly and linearly against increase of the fish weight. The grand mean of mercury concentrations related to the weight of fish was $0.163 ; 0.569 ; 0.723 ; 1.271$ and $1.606 \mathrm{mg} / \mathrm{kg}$ for A, B, C, D and E weight respectively. The rejection level of $1.0 \mathrm{mg} / \mathrm{kg}$ for swordfish set by EU-FVO was exceeded by $51(34 \%)$ out of 150 data gathered for swordfish.

The mean concentration of total mercury in the different weight of marlin are shown in Table 5. The average of total mercury levels ranged from the lowest of $0.014 \mathrm{mg} / \mathrm{kg}$ to the highest of $1.908 \mathrm{mg} / \mathrm{kg}$. A similar increasing trend of total mercury level with swordfish weight was also observed in marlin, of which total mercury increased significantly towards the increase of the fish weight. The grand mean of mercury levels related to the fish weight of marlin were $0.052 ; 0.172,0.702 ; 1.451$ and $1.895 \mathrm{mg} / \mathrm{kg}$ for A, B, C, D and E weight respectively. The rejection level of total mercury for marlin fish set by EU
FVO was $1.0 \mathrm{mg} / \mathrm{kg}$, where from 165 data gathered, 45 $(27.3 \%)$ data were exceeded.

Total mercury levels in yellowfin tuna and bigeye were ranged from $0.085-0.649 \mathrm{mg} / \mathrm{kg}$ and $0.49-0.514 \mathrm{mg} / \mathrm{kg}$ respectively. On the other hand, the level of total mercury in tuna-like ranged from $0.014-1.174 \mathrm{mg} / \mathrm{kg}, 0.056-1.657$ $\mathrm{mg} / \mathrm{kg}$ and $0.014-1.908 \mathrm{mg} / \mathrm{kg}$ for oilfish, swordfish, and marlin respectively. The mercury levels found in tuna (yellowfin and bigeye) tends to be lower compared to other tuna-like (swordfish, oilfish, and marlin). It is possibly due to differences in feeding habits, growth rate and tropics position (Bosch et al. 2016; Drevnick et al. 2015). Many studies have shown that mercury is bio-amplified in the food chain with high-tropic-level predatory species (such as shark, swordfish, and marlin) having higher mercury (Nicklisch et al. 2017), of which tuna-like are a greedier predator in their eating habits compared to tuna. Differences in feeding habit also dictate $\mathrm{Hg}$ levels in fish (Hosseini et al. 2014). According to Gobert et al. (2017), as the top predator, swordfish may be the end reservoir of the bioaccumulation of trace elements in a food chain because they occupy higher trophic levels and are an important food source, causing swordfish to be potentially hazardous to consume. Swordfish is considered apex predator and carry out very intensive metabolic activities that require a continuous supply of energy, and the rate of predation and food consumption is extremely high, which contributes notably to the accumulation of pollutants (Storelli et al. 2005). These data are also parallel with the rejection of fish products due to mercury content in European Union, of which in year 2016-2017, swordfish 71 and 82 cases, marlin 6 and 7 cases, and 1 and 3 cases for yellowfin from 100 and 117 cases fish products rejected respectively (EU Commission 2017).

The National Marine Fisheries Service (1978) measured total mercury in 250 individuals of several species of tuna, yielding a median of $0.12 \mathrm{mg} / \mathrm{kg}$ and a maximum of 0.87 
$\mathrm{mg} / \mathrm{kg}$. However, some studies on total mercury in tuna shown that total $\mathrm{Hg}$ was at a higher level, Plessi et al. (2001) reported an average of 0.249 in bluefin tuna, 0.85 $1.45 \mathrm{mg} / \mathrm{kg}$ in albacore from the Mediterranean (average $1.17 \mathrm{mg} / \mathrm{kg}$ ) with $78 \%$ exceeding $1.0 \mathrm{mg} / \mathrm{kg}$. Storelli et al. (2002) and Dezfouli et al. (2018) reported levels of mercury in canned tuna from the Persian Gulf of 0,074 to $0,311 \mathrm{mg} / \mathrm{kg}$. Moreover, there is evidence of variation among oceans and countries, probably related to the source of the fishery, species and fish weight.

\section{The effect of tuna and tuna-like weight on total mercury levels}

To measure the correlation between total mercury levels and the weight of tuna and tuna-like, linear regression analyses were applied. Yellowfin and bigeye ranged in weight from $1-10 \mathrm{~kg}$ (A weight) to $100 \mathrm{up} \mathrm{kg}$ (E weight), and grand mean of total mercury levels are weakly associated with the weight $(\mathrm{R} 2=0.0839$ and $\mathrm{R} 2=0.0784)$, as shown in Figure 1.

The weight of both tuna species did not affect total mercury levels. The grand mean of total mercury in all weight of yellowfin and bigeye were not exceeded 0.5 $\mathrm{mg} / \mathrm{kg}$, and $1.0 \mathrm{mg} / \mathrm{kg}$ as the maximum permitted a level of mercury in fish (tuna) for safe consumption set by many countries including EU-FVO (EU 2006).
A weak correlation was also found by Nicklisch et al. (2017) that fish ranged in length from $52.32 \mathrm{~cm}(10.1 \mathrm{~kg})$ to $139.5 \mathrm{~cm}(186 \mathrm{~kg})$ and methyl mercury levels were weakly associated. A similar weak relationship has been observed between mercury concentration and length of bluefin tuna (Colman et al. 2015). In contrast, a strong effect was observed when examining the impact of mercury level on swordfish and marlin fish weights ranged from $\mathrm{A}$ weight (1-10 kg) up to E weight (100 kg up). Total mercury levels were increased significantly and strongly correlated with the increment of the fish weight $(\mathrm{R} 2=0.9602$ and R2 $=0.9059$ ) as shown in figure 2 . The linear regression equation shows that the weight above of $50 \mathrm{~kg}$ (D weight) for swordfish and marlin have mercury levels tends to exceed of $1.0 \mathrm{mg} / \mathrm{kg}$ as a maximum permitted level of mercury level set by some countries including EU-FVO.

The mercury levels and weights of oilfish ranged from $1-5 \mathrm{~kg}$ (weight) up to $30-50 \mathrm{~kg}$ (E weight) were correlated as shown in Figure 3. (R2 =0.9063). The higher weight will increase the levels of mercury, although the mercury levels of both species are much lower compare to swordfish and marlin. Mercury levels of the biggest oilfish $(30-50 \mathrm{~kg})$ tend to exceed $1.0 \mathrm{ppm}$ as the maximum permitted mercury levels set by some countries including EU-FVO (EU 2006).

Table 3. The average of total mercury in oilfish (Ruvettus pretiosus)

\begin{tabular}{|c|c|c|c|c|c|c|c|c|c|c|c|}
\hline \multirow[b]{2}{*}{ Weight (kg) } & \multicolumn{7}{|c|}{ The average of total mercury $\mathrm{mg} / \mathrm{kg} /$ Processing plant } & \multirow[b]{2}{*}{ Grand mean } & \multirow[b]{2}{*}{ Median } & \multirow{2}{*}{$\mathbf{N}$} & \multirow[b]{2}{*}{ Std dev } \\
\hline & 1 & 2 & 3 & 4 & 5 & 6 & 7 & & & & \\
\hline A (1-5) & 0.014 & 0.014 & 0.056 & 0.105 & 0.043 & NA & 0.036 & 0.045 & 0.040 & 31 & 0.034 \\
\hline $\mathrm{B}(6-10)$ & 0.149 & 0.116 & 0.132 & 0.123 & 0.112 & NA & 0.095 & 0.121 & 0.120 & 32 & 0.018 \\
\hline $\mathrm{C}(11-15)$ & 0.321 & 0.336 & 0.299 & 0.363 & 0.359 & NA & 0.296 & 0.329 & 0.329 & 29 & 0.029 \\
\hline $\mathrm{D}(16-30)$ & 0.375 & 0.556 & 0.560 & 0.527 & 0.410 & NA & 0.647 & 0.513 & 0.542 & 30 & 0.102 \\
\hline $\mathrm{E}(30 \mathrm{UP})$ & 1.174 & 1.135 & 0.966 & 0.865 & 0.992 & NA & NA & 1.026 & 0.992 & 28 & 0.127 \\
\hline
\end{tabular}

Table 4. The average of total mercury in swordfish (Xiphias gladius)

\begin{tabular}{|c|c|c|c|c|c|c|c|c|c|c|c|}
\hline \multirow{2}{*}{ Weight (kg) } & \multicolumn{7}{|c|}{ The average of total mercury $\mathrm{mg} / \mathrm{kg} /$ processing plant } & \multirow{2}{*}{ Grand mean } & \multirow[b]{2}{*}{ Median } & \multirow{2}{*}{$\mathbf{N}$} & \multirow{2}{*}{ Std dev } \\
\hline & 1 & 2 & 3 & 4 & 5 & 6 & 7 & & & & \\
\hline$A(1-10)$ & 0.156 & 0.264 & 0.261 & 0.098 & 0.144 & 0.163 & 0.056 & 0.163 & 0.156 & 31 & 0.077 \\
\hline B (11-30) & 0.598 & 0.522 & 0.679 & 0.383 & 0.701 & 0.785 & 0.314 & 0.569 & 0.598 & 32 & 0.173 \\
\hline $\mathrm{C}(31-50)$ & 0.756 & 0.696 & 0.903 & 0.463 & 0.795 & NA & NA & 0.723 & 0.756 & 27 & 0.164 \\
\hline D (51-100) & 1.344 & 1.573 & 1.657 & 0.963 & 1.231 & 0.963 & 1.165 & 1.271 & 1.231 & 34 & 0.273 \\
\hline E (100 UP) & 1.592 & 1.648 & 1.606 & 1.593 & NA & 1.605 & 1.589 & 1.606 & 1.599 & 26 & 0.022 \\
\hline
\end{tabular}

Table 5. The average of total mercury in marlin (Macaira indica)

\begin{tabular}{|c|c|c|c|c|c|c|c|c|c|c|c|}
\hline \multirow{2}{*}{ Weight (kg) } & \multicolumn{7}{|c|}{ The average of total mercury $\mathrm{mg} / \mathrm{kg} /$ processing plant } & \multirow{2}{*}{ Grand mean } & \multirow{2}{*}{ Median } & \multirow[b]{2}{*}{$\mathbf{N}$} & \multirow[b]{2}{*}{ Std dev } \\
\hline & 1 & 2 & 3 & 4 & 5 & 6 & 7 & & & & \\
\hline $\mathrm{A}(1-10)$ & 0.058 & 0.014 & 0.048 & 0.062 & 0.048 & 0.042 & 0.090 & 0.052 & 0.048 & 34 & 0.023 \\
\hline B $(11-30)$ & 0.179 & 0.149 & 0.171 & 0.166 & 0.174 & 0.180 & 0.188 & 0.172 & 0.174 & 40 & 0.013 \\
\hline $\mathrm{C}(31-50)$ & 0.842 & 0.692 & 0.657 & NA & 0.682 & 0.724 & 0.616 & 0.702 & 0.687 & 35 & 0.078 \\
\hline $\mathrm{D}(51-100)$ & 1.682 & 0.986 & 1.350 & 1.854 & 1.389 & 1.446 & NA & 1.451 & 1.418 & 32 & 0.299 \\
\hline E (100 UP) & 1.902 & 1.896 & 1.908 & 1.882 & NA & 1.890 & 1.889 & 1.895 & 1.893 & 24 & 0.010 \\
\hline
\end{tabular}




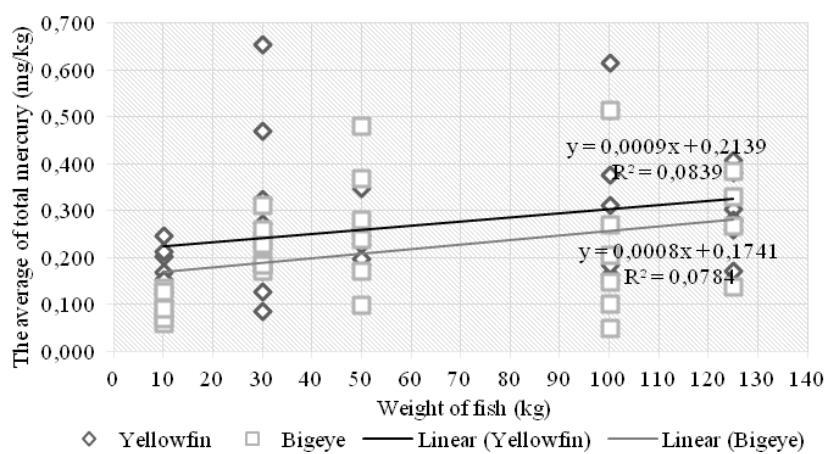

Figure 1. Correlation between mercury concentration and weight of yellowfin and bigeye

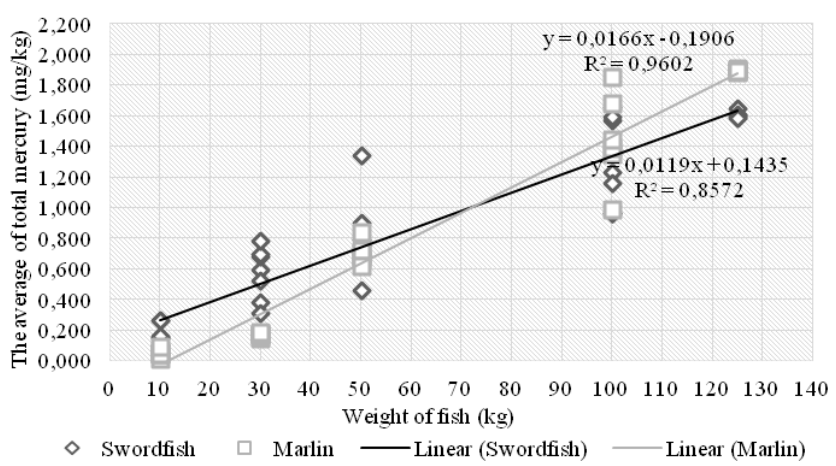

Figure 2. Correlation of between mercury concentration and weight of swordfish and Marlin

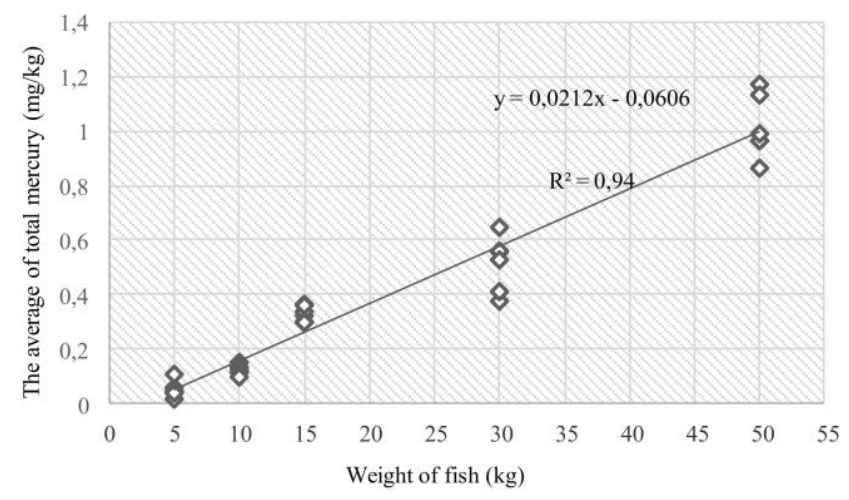

Figure 3. Correlation of between mercury concentration and weight of oilfish

\section{Provisional tolerable weekly intake}

A joint FAO/WHO expert committee has recommended a provisional tolerable weekly intake (PPTWI) of mercury at the concentration of $5 \mu \mathrm{g} / \mathrm{kg}$ body weight. For an adult weighing $60 \mathrm{~kg}$, maximum mercury accumulation per week is $300 \mu \mathrm{g}$ (WHO 2014). The highest mercury levels grand mean of yellowfin and bigeye were 0.331 and $0.327 \mathrm{mg} / \mathrm{kg}$ respectively, of which below $1.0 \mathrm{mg} / \mathrm{kg}$ as the maximum permitted levels set by many countries including EU-FVO.
Tolerable weekly intake (PTWI) for tuna (yellowfin and bigeye) with the highest mercury levels of $0.33 \mathrm{mg} / \mathrm{kg}$, the maximum consumption is about $909 \mathrm{~g}$, with maximum consumption about $714 \mathrm{~g}$ per week in order to accumulate $300 \mu \mathrm{g}$ of mercury in a week which is the limit set by FAO/WHO expert committee on food additive. These mean that for oilfish with weight lower than $30 \mathrm{~kg}$ which has lower mercury concentrations, can be consumed more than $714 \mathrm{~g}$ per week before exceeding the PTWI. The highest concentrations of oilfish, swordfish, and marlin were $1.026 ; 1.606$ and $1.895 \mathrm{mg} / \mathrm{kg}$ respectively, where weight $30 \mathrm{~kg}$ up for oilfish and $50 \mathrm{~kg}$ up for swordfish and marlin tend to exceed the mercury levels of $1.0 \mathrm{ppm}$ as a maximum level set by many countries.

The grand mean mercury levels of oilfish lower than 30 $\mathrm{kg}$ are $0.513 \mathrm{mg} / \mathrm{kg}$ and for swordfish and marlin lower than weight $50 \mathrm{~kg}$ were 0.723 and $0.702 \mathrm{mg} / \mathrm{kg}$. Maximum consumption of oilfish per week is about $600 \mathrm{~g}$ and $400 \mathrm{~g}$ for swordfish and marlin and can be higher for fish weight lower than $50 \mathrm{~kg}$ before exceeding PTWI.

In conclusions, the meat fish is highly appreciated for being tender and delicious and for the beneficial influence of its nutrient: high-quality protein, n-3 fatty acids, vitamins, and minerals. However, consumption of large predatory fish (tuna and tuna-like) may place an individual at risk of serious illness due to high levels of mercury. It has been shown that mercury level in tuna (yellowfin and bigeye) were substantially lower than in tuna-like (swordfish, marlin, and oilfish), whereas all mercury levels in tuna did not exceed $1.0 \mathrm{mg} / \mathrm{kg}$ and the weight of tuna species does not affect mercury contents. These data, particularly for mercury in tuna-like (swordfish, marlin, and oilfish), indicate the desirability of instituting a regular monitoring program for exported and consumed products. PTWI calculation indicates that people who are not in highrisk categories (most adult and adolescents) may consume about $1,000 \mathrm{~g}$ of tuna per week and lesser for tuna-like (swordfish, oilfish, and marlin). Pregnant or soon to be pregnant women, infants, and small children should limit tuna-like intake and select tuna rather than tuna-like. It is highly recommended that intensive monitoring program of mercury levels for tuna-like (swordfish, marlin, and oilfish) should be carried out both by processing plants and governments authority for the continuation of trading, industries and in the prespective of public health.

\section{REFERENCES}

Bosch AC, O'Neill B, Sigge GO, Kerwath SE, Hoffman LC. 2016. Mercury accumulation in Yellowfin tuna (Thunnus albacares) with regards to muscle type, muscle position and fish size. Food Chem 190: $351-356$

Colman JA, Nogueira, JI, Pancorbo OC, Batdorf CA, Block BA. 2015. Mercury in Pacific bluefin tuna (Thunnus orientalis): bioaccumulation and trans-Pacific Ocean migration. Can J Fish Aquat Sci 72: 1015-1023.

Daniels JL. Longnecker MP, Rowland AS, Golding J. 2004. ALSPAC Study Team University of Bristol Institute of Child Health. Fish intake during pregnancy and early cognitive development of offspring. Epidemiology 15 (4): 394-402. 
Dezfouli AB, -Amoli SJ, Esfahani TA, Hosseini H, Ghanati K. 2018. Evaluating Total Mercury and Methyl Mercury Contents in Canned Tuna Fish of the Persian Gulf. Iran J Pharm Res 17 (2): 585-592.

Drevnick PE, Lamborg CH, Horgan MJ. 2015. Increase in mercury in Pacific yellowfin tuna. Environ Toxicol Chem 9999: 1-4.

EFSA [European Food Safety Authority. 2015. Statement on the benefits of fish/seafood consumption compared to the risks of methylmercury in fish/seafood. EFSA J 13 (1): 3982.

Commission E. Commission Regulation [EC] No. 1881/2006 of 19 December 2006 Setting maximum levels for certain contaminants in foodstuff. 2006. 2006R1881-EN-01.09. 2014-014.001-1

FDA [Food and Drug Administration]. 2001. FDA consumer advisory. www.cfsan.fda.gov./-dms/hgpdftoc.html

European Commission. 2017. Rapid Alert System for Food and Feed (RASFF). http://ec.europa.eu/food/food/rapidalert/index_en.htm. [ 30 April 2018].

Galand G, Rogers A, Nickson A. 2016. Netting billions: A global valuation of tuna. Global tuna conservation. The Pew Charitable Trust Fund, Washington, US.

Gobert S, Pasqualini V, Dijoux J, Lejeune J, Durieux EDH, Marengo M. 2017. Trace element concentrations in the apex predator swordfish (Xiphias gladius) from a Mediterranean fishery and risk assessment for consumers. Mar Pollut Bull 120 (1-2): 364-369.

Hosseini M, Nabavi SMB, Parsa Y, Nabavi SN. 2014. Mercury accumulation in food chain of fish, crab and sea bird from Arvand River. J Marine Sci Res Dev 4: 148.

Lavoie RA, Bouffard A, Maranger R, Amyot M. 2018. Mercury transport and human exposure from global marine fisheries. Sci Rep 8: 6705

Mahaffey KR, Sunderland EM, Chan HM, Choi AL, Grandjean P, Marien K, Oken E, Sakamoto M, Schoeny R, Weihe P, et al. 2011. A. balancing the benefits of $n-3$ polyunsaturated fatty acids and the risks of methylmercury exposure from fish consumption. Nutr Rev 69 493-508.

Okyere H, Voegborlo RB, Agorku SE. 2015. Human exposure to mercury, lead and cadmium through consumption of canned mackerel, tuna, pilchard, and sardine. Food Chem 179: 331-335.
PARM [Poseidon Aquatic Resource Management. 2016. Study of the global estimate of the value of tuna fisheries-Phase 3 Report. Poseidon Aquatic Resource Management Ltd., Hampshire, UK.

Plessi M, Bertelli D, Monzani A. 2001. Mercury and selenium content in selected seafood. J Food Composit Anal 14: 461-467.

Lacerda LD, Goyanna F, Bezerra MF, Silva GB. 2017. Mercury Concentrations in Tuna (Thunnus albacares and Thunnus obesus) from the Brazilian Equatorial Atlantic Ocean. Bull Environ Contam Toxicol 98:149-155.

Sackett DK, Cope WG, 2, Rice JA, Aday DD. 2013. The influence of fish length on tissue mercury dynamics: Implications for natural resource management and human health risk. Intl J Environ Res Public Health 10: 638-659.

Storelli MM, Stuffler RG, Marcotrigiano GO. 2002. Total and methylmercury residues in tuna-fish from the Mediterranean Sea. Food Addit Contam 19: 715-720.

Storelli MM, Giacominelli-Stuffler R, Storelli A, Marcotrigiano G.O. 2005. Accumulation of mercury, cadmium, lead and arsenic in swordfish and bluefin tuna from the Mediterranean Sea: a comparative study. Mar Pollut Bull 50: 1004-1007.

Storelli MM, Giacominelli-Stuffler R, Storelli A, Marcotrigiano G.O. 2006. Relationship between total mercury concentration and fish size in two pelagic fish species: Implications for consumer health. J Food Protect 69 (6): 1402-1405.

NMFS [National Marine Fisheries Service. 1978. Survey of Trace Elements in the Fishery Resource. NOAA Technical Report NMFS SSRF-721. National Marine Fisheries Service, Silver Spring, MD.

US Department of Agriculture and US Department of Health and Human Services. Dietary Guidelines for Americans. 2010 seventh ed. US. Government Printing Office, Washington DC.

WHO [World Health Organization]. 2014. Summary Report of the Seventy-Third Meeting of JECFA. Joint FAO/WHO Expert Committee on Food Additives, Geneva, Switzerland.

Walpole RE. 1982. Introduction of Statistics. 3rd ed. Macmillan Publishing Company, Inc., New York. 